\title{
Modeling of Temperature Regimes of Energy Efficiency House
}

\author{
Semjon Kundas ${ }^{1 *}$, Elena Kresova ${ }^{2}$, Yurij Suprinovich ${ }^{3}$ \\ ${ }^{1}$ Department of Heat and Gas Supply and Air-Conditioning, Belarusian National Technical University, Minsk, \\ Belarus \\ ${ }^{2}$ Faculty of Environmental Monitoring, International Sakharov Environmental Institute, Minsk, Belarus \\ ${ }^{3}$ International Charitable Public Association "EcoBuilder", Minsk, Belarus \\ Email: "kundas@tut.by, elena-kresova@mail.ru, oekodom@gmail.com
}

Received 20 October 2015; accepted 5 November 2015; published 12 November 2015

Copyright (C) 2015 by authors and OALib.

This work is licensed under the Creative Commons Attribution International License (CC BY).

http://creativecommons.org/licenses/by/4.0/

(c) (i) Open Access

\begin{abstract}
3-D thermal model of energy efficiency house for rural areas is proposed. For research and optimization of thermal regimes and envelopes structure constructive, finite element and computational models are developed. These models are practically implemented in the software packages SolidWorks and COMSOL Multiphysics. Created model allows calculating 3-D temperature field of building with local heat insulator materials using free available software. Method: Computer modeling. Additional object-air environment of the building-was created for modeling process of heat transfer in the whole volume of building. The simulation was performed using supercomputer "SKIF" in United Institute of Informatics Problems of National Academy of Science of Belarus. Using methods of thermal analysis verification of developed models is done. Error of simulation results does not exceed $10 \%$. It allows using thermal model to solve problems of analysis and optimization of thermal conditions of buildings and to choose heat insulation materials.
\end{abstract}

\section{Keywords}

Heat Transfer, Modeling, Temperature, Energy Efficiency, Building

Subject Areas: Applications of Communication Systems

\section{Introduction}

At present, there are a lot of houses which are built with environmentally friendly local materials especially in individual housing construction [1]. "Environmentally friendly" houses can be viewed from several aspects: usage of natural, environmentally friendly and environmentally-friendly materials, usage of biotechnology at

${ }^{*}$ Corresponding author. 
disposal of waste products, and usage of natural energy sources [2].

"Ethnic environmentally friendly construction" is developed as well [2]. It is revival of old technologies that have been used in rural buildings in varying areas. So technology as a straw building revives within this direction. Today, there are two directions of straw construction: house which was made of pressed straw blocks and frame houses (the type fachwerk) from straw-clay filled or block filling [3].

In Belarus International Charitable Public Association "EcoBuilder" began to develop the direction of environmentally friendly individual building [4]. According to technology of this organization individual houses were built in the village Stahovtsy, Myadel district, Minsk region and in the village Old Lepel, Lepel district, Vitebsk region. Currently, Private Production Unitary Enterprise "EcoBuilder" is active promoting this direction at Belorussian market [3] [5].

Application of new insulating materials requires research of their efficiency, especially if these materials are used in multilayer structures. Perspective direction of solving this problem is a computer simulation [1]. Often it is impossible to apply modern commercial software systems according to specifications for these purposes without their adaptation and refinement. Therefore, the aim of this work is developing of models which describe thermal characteristics of analyzed home with possibility of these models practical usage in software COMSOL Multiphysics and conducting research of efficiency of local thermal insulation envelope materials.

\section{Construction Features of Modeling Objects}

In the village Stahovtsy there are homes with three different types of envelopes. All three options of buildings have the same wall structure from clay and straw. Thickness of this layer is $40 \mathrm{~cm}$. But they have different options of external thermal insulation: option 1-two layers of reed mats (thickness of each layer is $5 \mathrm{~cm}$ ), option 2-a single layer of plastic foam of $5 \mathrm{~cm}$ and without additional insulation (option 3). Coverage of the roof in all cases is reed (thickness is $300 \mathrm{~mm}$ ) (Figure 1) and environmentally friendly cellulose wadding as internal insulation (thickness is $210 \mathrm{~mm}$ ) [6]. In the present study we investigated the first variant of home.

As already mentioned, house walls were made from a mixture of clay and straw. Straw and clay, along with high thermal insulation properties, are capable of absorbing moisture from air and donating it back at excessive dryness. Thanks to this a favorable microclimate is always in clay buildings. Optimal for human humidity (50\% - 55\%) is saved in houses. Such buildings "breathe", that's why they don't need expensive ventilation and air-conditioning systems. At service life they are superior to stone and wooden houses. Clay has a high fire resistance, prevents development of mold and bacteria and prevents the occurrence of micropollutants. Such building also has a good sound insulation.

Figure 2 shows the construction of wall of investigated house which was made on frame technology with wall filling of a mixture of clay and straw by slip forming method. This picture was get from Building Project of house [6].

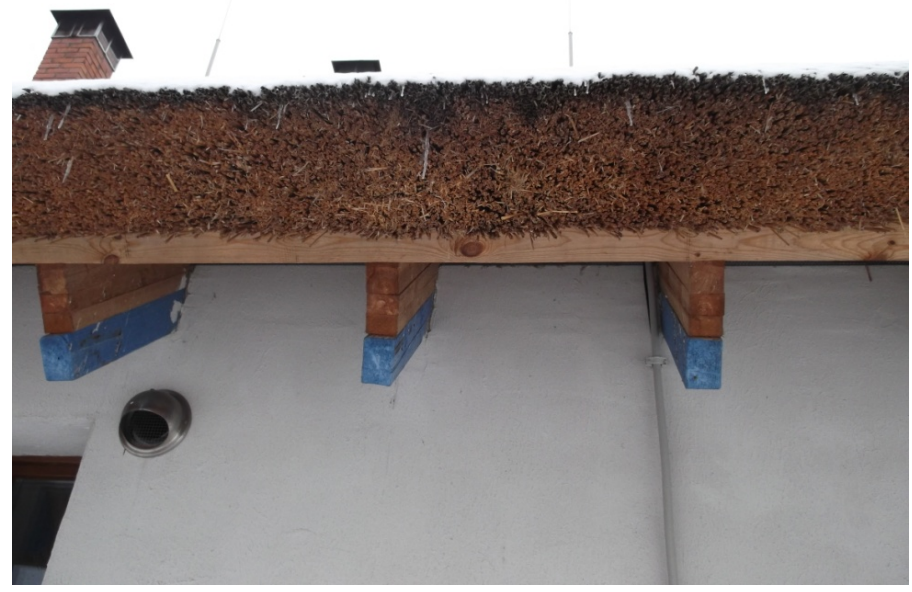

Figure 1. General view of roof insulation of investigated house. 


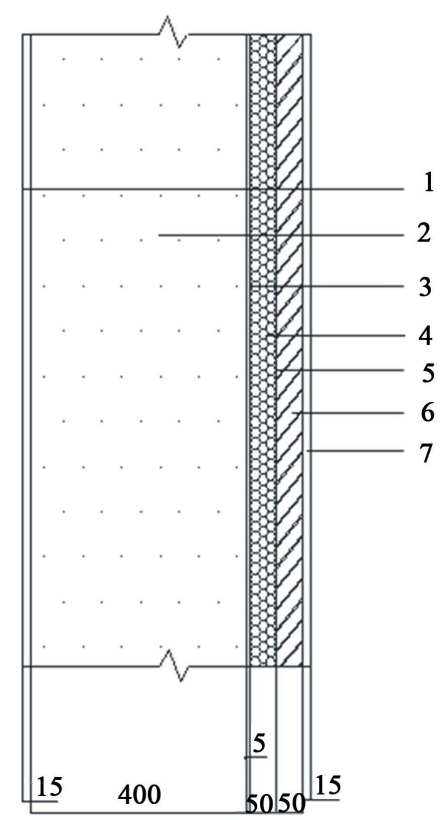

Figure 2. Construction of wall.

where 1 -clay plaster $15 \mathrm{~mm}$;

2-clay + straw $(400 \mathrm{~mm})$;

3-clay plaster $5 \mathrm{~mm}$;

4-plate $50 \mathrm{~mm}$ (horizontal position of stem);

5-vapor barrier film;

6-reed plate $50 \mathrm{~mm}$ (vertical position of stem);

7-plaster of building mixtures "Zabudova".

Frame house is made from thick timber. Beams, rafters, interior partitions are made from thick timber as well. Dimensions of timber are from $12 \times 20 \mathrm{~cm}$ to $12 \times 12 \mathrm{~cm}$ for interior walls. Wood necessarily is daubed with clay. It creates a safe environment in relation to fire. As mentioned above, wall space between timbers are filled with a mixture of chips and clay ( $90 \%$ - straw, $5 \%-10 \%$ —lay).

Milled straw is mixed with clay and water. Then this mixture settles in specially excavated pits. After the mixture reaches desired consistency it can be used to perform walls and other structures. Formwork of wooden shields is attached to frame of house. Then space between frame and formwork is filled with mixture. This operation is performed manually. After curing the mixture formwork is removed. When the execution of building envelopes is finished you can not immediately begin finishing work. The house should stand in such unfinished appearance at least one winter. During this time, shrinkage of the wall material happens which should be eliminated. Builders have to work manually: cracks are covered up with clay and are hammered with tow. If you do not, in future large heat losses are inevitable. And finally, when building envelopes are finished it begins execution of internal and external finishing works. Outside house is upholstered with reed plates in 2 layers of $5 \mathrm{~cm}$. Own production of reed plates is established by "EcoBuilder" in the village. Zanaroch. Reed plates have thermal conductivity is $0.067 \mathrm{~W} /\left(\mathrm{m} \cdot{ }^{\circ} \mathrm{C}\right)$. Then from the outside house is plastered [7].

Application as insulating material reed plates provides a number of advantages:

- In manufacture of reed plates harmful to health chemicals are not used.

- Production of plates doesn’t require large consumption of energy. Energy is spent mainly for their transportation.

- Rough surface of plates provides a good foundation for clay plaster.

- Plates are good thermal insulation material: they retain heat in winter and cool air in the summer. Insulation delay heat flow from atmospheric air into the wall thereby it decreases its temperature [8].

The process of construction of studied houses conventionally comprises the following steps:

- Implementation of framework from timber of natural humidity used sections of timber as mentioned are 120 
$\times 120 \mathrm{~mm}, 120 \times 200 \mathrm{~mm}, 80 \times 200 \mathrm{~mm}$.

- Filling walls, floors, space between rafters with a mixture of clay, straw (wood chips) and water. This mixture is directly prepared at construction site using slip forming method.

- Technological pause for drying (of two to six months).

- Thermal insulation of homes using thermal insulation plates from reed of own production and laying isolating film.

- Finishing work. Inner plaster is performed by a special reed grid with clay mortar [4].

For investigated house thermal calculation of thermal resistance of building envelope was made [9] which reached $3233 \mathrm{~m}^{2 \circ} \mathrm{C} / \mathrm{W}$ (Table 1). Normative value values of thermal resistance for exterior walls must be at least $3.2 \mathrm{~m}^{2 \circ} \mathrm{C} / \mathrm{W}$ [10]. Specific consumption of thermal energy for heating of home is calculated as well. It amounted $56.6 \mathrm{~kW} \cdot \mathrm{h} / \mathrm{m}^{2}$. According to regulatory documents [11], examined object belongs to a class of energy efficient buildings (class B).

Heating and hot water supply of investigated home was carried out using boiler room. Boiler Peletti II SR 153 (Table 2) is made in Germany and is the basis of this boiler room. Wood pellets are used as fuel in the boiler (Figure 3). Boiler heat scheme provides automatic maintenance the temperature of network water for heating and ventilation depending on outside temperature.

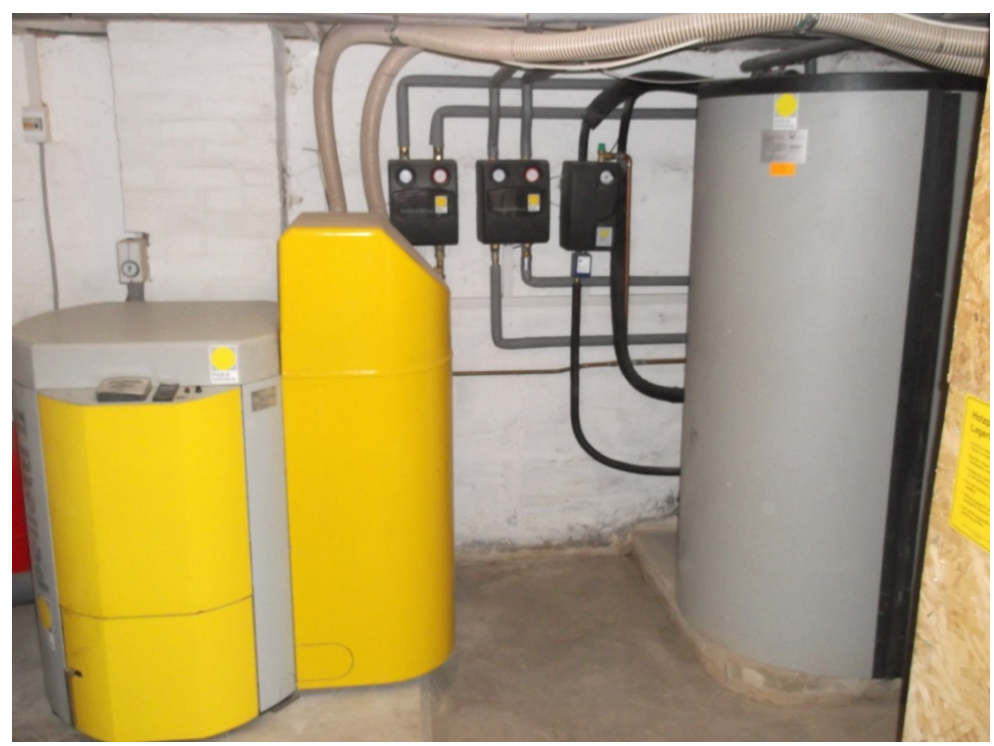

Figure 3. General view of boiler equipment.

Table 1. Technical characteristics of building envelopes.

\begin{tabular}{lcccc}
\hline № & Material name & Thickness, $(\mathrm{m})$ & $\begin{array}{c}\text { Thermal conductivity, } \\
\left(\mathrm{W} /\left(\mathrm{m} \cdot{ }^{\circ} \mathrm{C}\right)\right)\end{array}$ & $\begin{array}{c}\text { Thermal resistance, } \\
\left(\mathrm{m}^{2} \cdot{ }^{\circ} \mathrm{C} / \mathrm{W}\right)\end{array}$ \\
\hline 1 & Clay plaster & 0.015 & 0.81 & 0.019 \\
2 & Mixture of clay and straw & 0.4 & 0.3 & 1.333 \\
3 & Clay plaster & 0.005 & 0.81 & 0.006 \\
4 & Eaves boards & 0.032 & 0.17 & 0.188 \\
5 & Reed plate & 0.05 & 0.067 & 0.746 \\
6 & Steam insulation film & 0.001 & 0.17 & 0.746 \\
7 & Reed plate & 0.05 & 0.067 & 0.030 \\
8 & Plaster of mixtures & 0.015 & 0.5 & 3.075
\end{tabular}


Table 2. Technical characteristics of boiler.

\begin{tabular}{cccc}
\hline № & Name of feature & Unit of measurement & Value \\
\hline 1 & Heat productivity & $\mathrm{kW}$ & $5-15$ \\
2 & Operating pressure & $\mathrm{kPa}$ & 350 \\
& Rated water temperature & & 90 \\
3 & Output & ${ }^{\circ} \mathrm{C}$ & 70 \\
& Input & ${ }^{\circ} \mathrm{C}$ & $1.2-3.5$ \\
4 & Fuel consumption, rated & $\mathrm{kg} / \mathrm{h}$ & 92.6 \\
\hline
\end{tabular}

Solar collector is used in hot water supply systems of home as well (Figure 4). This collector is installed on the wall of attic floor saves heat which goes on hot water heating. 140 days of year (April-October) water heating for hot water supply is carried out only with the help of solar collector Paradigma CPC Azzurro.

\section{Thermal Model of Building}

Thermal model of house with walls filled with clay and straw and reed insulation is realized in the software package COMSOL Multiphysics. For practical usage of this model constructive, finite element and calculation models were developed additionally. Boundary and initial conditions are formulated.

\subsection{Constructive Model}

Constructive model of a typical house is developed using software package Solid Works. Developed model shows spatial geometric relations between elements of object (Figure 5).

Additional object was introduced in proposed constructive model, namely air environment inside building. This object allows to avoid fixed temperature at inner boundary of envelope as boundary condition [12].

\subsection{Finite Element Model of House}

Finite element model of house was developed on the basis of constructive model using COMSOL Multiphysics. This model consists from a mesh of tetrahedrons. In constructing the mesh it was taken into account that it was not less than ten finite elements between any two boundaries.

Irregular tetrahedral mesh meets the following requirements in physical space:

- thicken in areas where heat transfer is the most interesting;

- thicken at curved surfaces to better repeat its geometry.

\subsection{Computational and Analytical Model}

In computational and analytical model loads and constraints are attached to faces of model or to nodes of finite elements. Properties of applicable materials are described as well.

\section{Results of Numerical Studies and Experimental Verification of Developed Models}

\subsection{Initial and Boundary Conditions}

Initial air temperature inside the room was $22^{\circ} \mathrm{C}$, initial air temperature of walls, windows was $18^{\circ} \mathrm{C}$. Temperature on the outside surface of building envelopes and on the outside surface of windows was assumed to be equal a change of outdoor temperature during the entire time of numerical studies (24 hours). Process of cooling the house during a day after heating disconnecting was investigated. The simulation was performed using supercomputer "SKIF" [13].

\subsection{Methods of Experimental Studies}

Experimentally every two hours outside air temperature was measured, temperature from external wall side and 


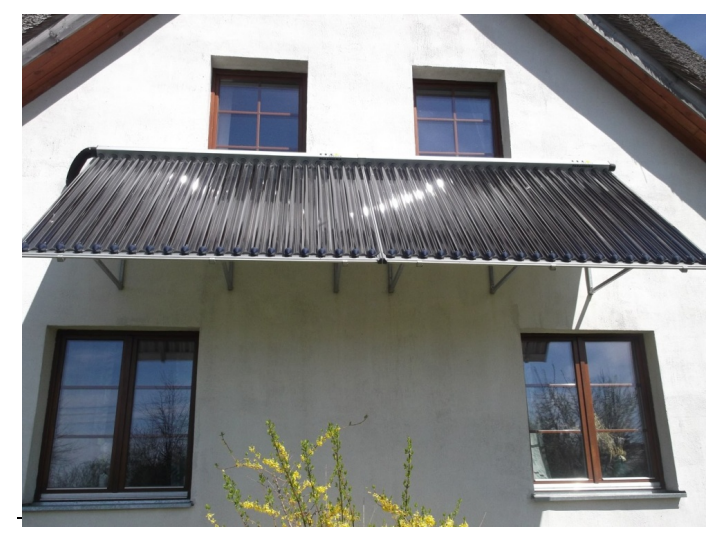

Figure 4. General view solar collector.

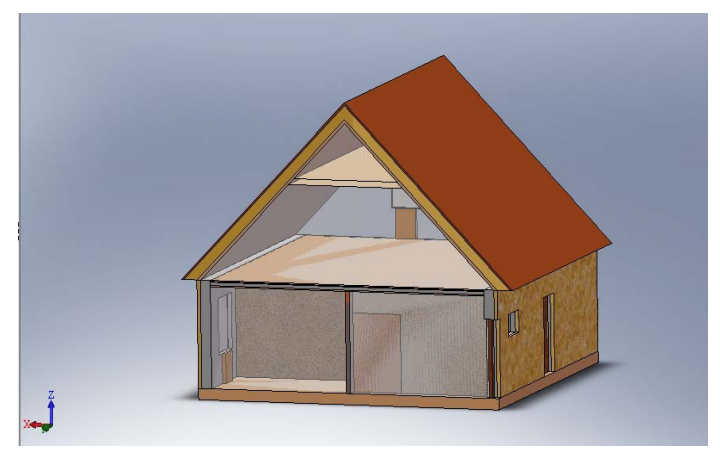

Figure 5. Constructive model.

inner wall side, temperature of battery, indoor air, floor and ceiling were measured was measured experimentally every two hours as well. For measurements we used a thermal imager FLIR i3 which has a measurement error $( \pm 2 \%)$ and a temperature sensitivity of $0.15^{\circ} \mathrm{C}$.

\subsection{Results of Numerical and Experimental Studies}

As seen from Figure 6 temperature inside the house during 24 hours decreased from $22^{\circ} \mathrm{C}$ to approximately $15^{\circ} \mathrm{C}$. Due to existing specific heat loss to environment temperature of wall surface (Figure 7) is slightly lower $\left(19^{\circ} \mathrm{C}\right)$. However, this temperature difference between experimental and modeling values during cooling house is reduced to $1{ }^{\circ} \mathrm{C}$, which is natural because of decrease of temperature difference inside and outside the house. Experimental measurements correspond to modeling results. As follows from Figure 6, Figure 7, error of numerical calculations is about $10 \%$. That's why it is possible to talk about adequacy of developed models and their practical applications [14].

As seen in Figure 8, the floor temperature is reduced more than wall temperature. Conducted thermovision studies the external side of home confirm results of simulation (Figure 9). Thermogram shows that temperature of house foundation higher than temperature of walls. It indicates about potential heat loss through the bottom part of the house (floor). Wall temperature from external side of the house slightly higher at the beginning of experiment (when heating is). It can be explained by higher heat transfer through the wall at higher temperature gradient [15].

\section{Conclusions}

A technique of creation of thermal model of individual house for rural areas based on new local heat insulator materials is developed. This technique provides creation of constructive, finite element and computational models and algorithm of its computer implementation.

3-D thermal model of individual house is developed. In proposed model in contrast to known solutions additional object-air environment of the building — was created for modeling process of heat transfer in the whole 


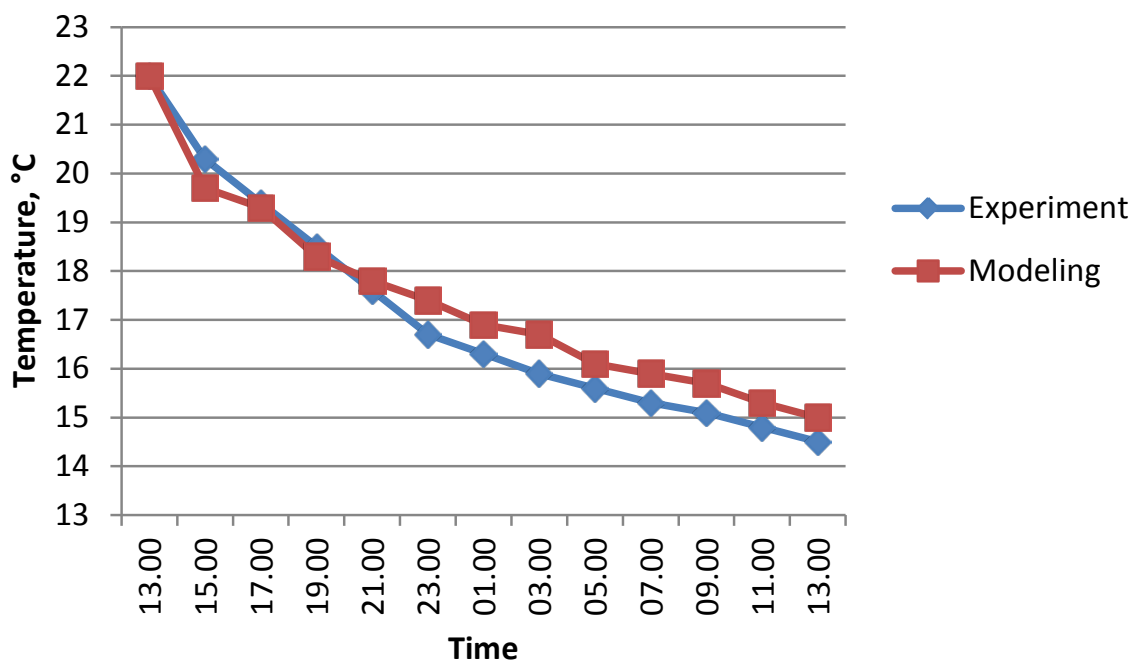

Figure 6. Changing air temperature inside the house during cooling.

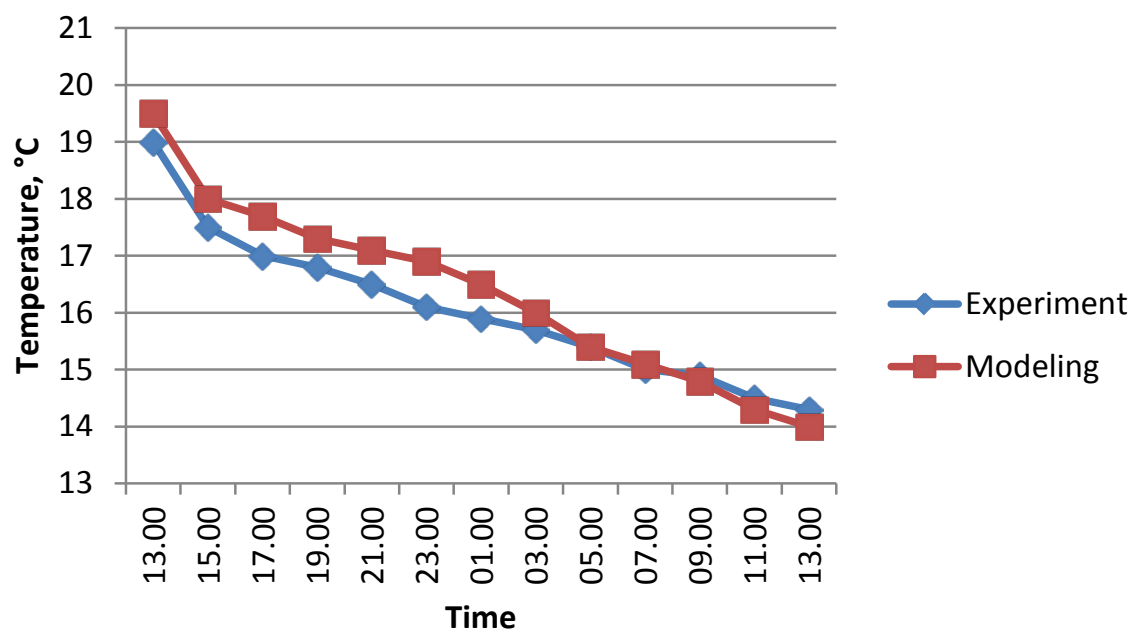

Figure 7. Changing air temperature on surface of walls inside the house.

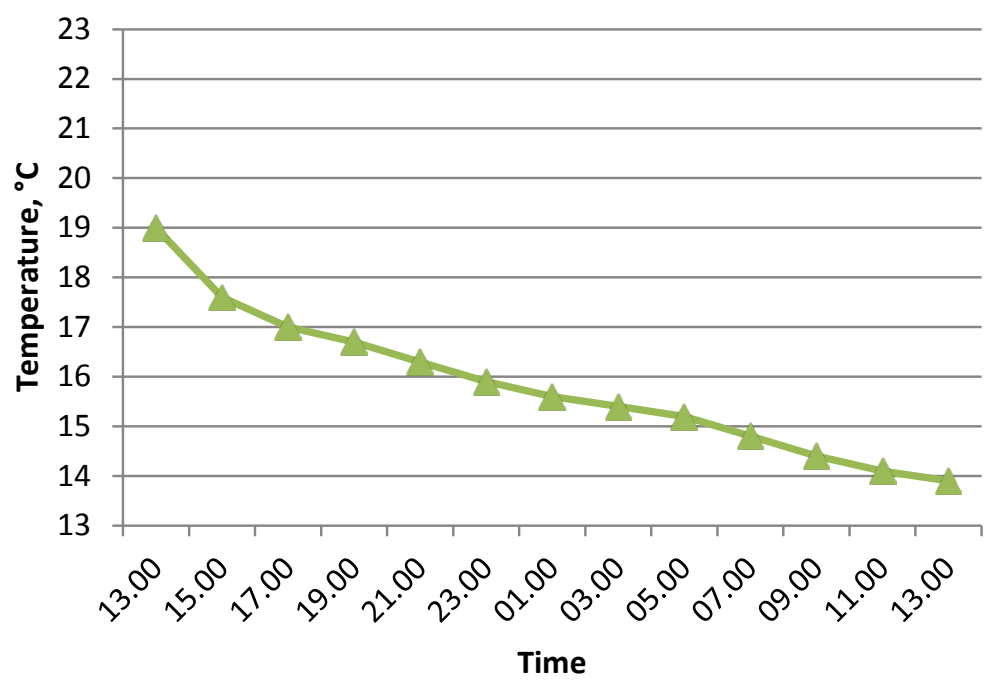

Figure 8. Changing floor temperature in process of cooling the house during experiment. 


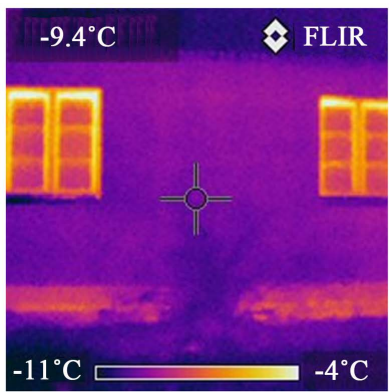

(a)

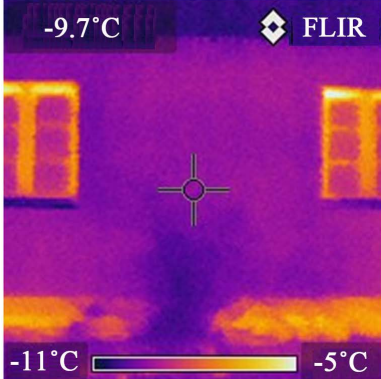

(b)

Figure 9. Thermograms of the house (a) before turning off heating; (b) the next day after turning off heating.

volume of building. It avoids setting a fixed temperature at the inner boundary enclosing structure as a boundary condition.

Analysis of heat transfer process was made for different variants of building envelopes of individual house on the basis of local heat insulator materials using created 3-D thermal models. It has been shown that the preferred variant of insulation is a variant of insulation with location of reed plates from the outer side of wall. All sharp fluctuations of ambient temperature are perceived with reed insulation which has high damping properties. Therefore service life of main insulation in construction of walls increases by reducing arising thermal strains.

Carried out with the help of developed integrated model numerical studies of thermal regimes of individual house which was built with technology of company "EcoBuilder" and their experimental verification confirmed efficiency, reliability of proposed models (error of simulation results does not exceed 10\%), possibility of using for solving tasks of analysis of thermal regimes and optimization of building envelopes.

\section{Acknowledgements}

The authors are thankful to United Institute of Informatics Problems of National Academy of Science of Belarus for possibility to use supercomputer "SKIF".

\section{References}

[1] Yalunina, O.V. and Bessonov, I.V. (2003) Environmental Aspects of Usage of Wall Materials, Actual Problems of Building Thermal Physics. Proceedings of NIISF, Moscow, 181-187.

[2] Titarenko, L.G. (2013) The Ecological Values of the Population in the Republic of Belarus: Theoretical and Empirical Levels. Sociological Almanac, 4, 352-359.

[3] (2015) Myadel District Executive Committee. http://myadel.minsk-region.by/

[4] (2015) International Charitable Public Association "EcoBuilder”. http://www.oekodomstroj.by/

[5] Galinko, I. (2015) Building. Green Building in Lepel District: It Is Planned to Construct a Day Stay Building for Persons with Disabilities. Architecture and Construction Portal. http://ais.by/

[6] Building Project (2010) Thermal Upgrading with Replacement Boiler Equipment and Installation of Solar Collector in Administrative Buildings ICPO "Eco Home” in the Village Stahovtsy. Architectural Solutions.

[7] Sadovskaja, E. (2015) Energy Efficiency and Conservation. German Technology with US. Architecture and Construction Portal. http://ais.by/

[8] Training Seminars and Workshops (2010) Energy Efficient on Struction: Reed Roof and Thermal Rehabilitation of Frame House. Proceedings, Stahovtsy.

[9] Technical Code of Good Practice 45-2.04-43-2006 (02250) (2006) Building Heating Engineer. Building Design Standards. Minsk, RUE “Stroitechnorm”, 56.

[10] New Normative Values of Thermal Resistance of Building Envelopes (2009) On the Design and Construction of Energy Efficient Buildings. Letter № 06-1-05/1043 from 04.03.

[11] Technical Code of Good Practice 45-2.04-196-2010 (02250) (2010) Buildings Thermal Protection. Heat Power Characteristics. Rules of Definition. Minsk, Ministry of Architecture and Construction of Belarus, 20.

[12] Kresova, E.V. and Kundas, S.P. (2015) The Thermal Model of Individual House. Informatics, 1, 56-63. 
[13] Abramov, S.M., Anischenko, V.V., Paramonov, N.N., Rymarchuk, A.G. and Chizh, O.P. (2013) Sectoral Supercomputers Family of "SKIF" in Belarus: State and Development Prospects. Scientific Service in the Internet: All Facets of Parallelism. Proceedings of International Supercomputer Conference, Novorossiysk, 23-28 September 2013, $258-263$.

[14] Kresova, E.V., Kundas, S.P., Kuzhelko, D.Yu. and Suprinovich, Yu.L. (2015) Energy Efficiency Analysis of Individual House Which Was Built by Design of Firm “EcoBuilder”. Proceedings of Sakharov Readings 2015: Environmental Problem of the XXI Century, ISEU, Minsk, 21-22 May 2015, 290.

[15] Kundas, S.P. and Kresova, E.V. (2015) Thermal Modes Simulation of Energy Efficient Building. Proceedings of Alternative \& Renewable Energy Sources as Alternative Primary Energy Sources in the Region, Lvov, 2-3 April 2015, 248-252. 